\title{
The 2013-2018 interdisciplinary summer workshops around the wooden monument church in Crivina de Sus village, Romania
}

\author{
Vladimir Obradovici ${ }^{1, *}$ \\ ${ }^{1}$ Politehnica Timişoara, faculty of Architecture and Urbanism, Piaţa Victoriei Nr. 2 Timişoara \\ 300006, jud. Timiş, România
}

\begin{abstract}
This article describes an ongoing project, starting in 2013, in which interdisciplinary summer workshops were held in Crivina de Sus, Timis County, Romania, attended by specialists and students from different fields. Within these workshops, it was watched as a Cultural Landscape and its components could be viewed and studied from different perspectives of related specialties in order to obtain a comprehensive and complete picture of the context. These specialties have taken account of each other and have learned the methods and points of view specific to each field. Following these workshops, the conclusions of the studies were summed up and used in a project to promote, value and improve the cultural landscape.
\end{abstract}

\section{Background}

This article presents an ongoing research and education project started in 2013 in the village Crivina de Sus in the western part of Romania, where studies of the cultural landscape were carried out in interdisciplinary teams of specialists and students. This article presents the whole process carried out until now, divided in three main branches: landscape, sociology/anthropology and architecture.

In the period 2012-2014, the Association of Landscape Architects of Romania (AsoP, West Territorial Branch) obtained funding for three years study for the research of the rural cemeteries in Banat and their relationship with the cultural landscape they belong to, through the A.F.C.N. Program. (Administration of the National Cultural Fund) of the Ministry of Culture [1]. In the first year of research (2012) we looked at the subject in the big scale "The Cemetery as an element in the evolution of the cultural landscape; case study: Banat Rural Cemeteries ". The entire Banat region, which is today in Romania, was studied as a multiethnic and multi-cultural space. Based on certain methodological criteria, the ethnographic sub-areas that make up the territory of Banat were separately studied, the character of these sub-areas reflected specific ways in which different ethnic and religious cultures materialized their village-cemetery, the place of household and the relationships between them. [2]

\footnotetext{
* Corresponding author: vladimir.obradovici@yahoo.com
} 


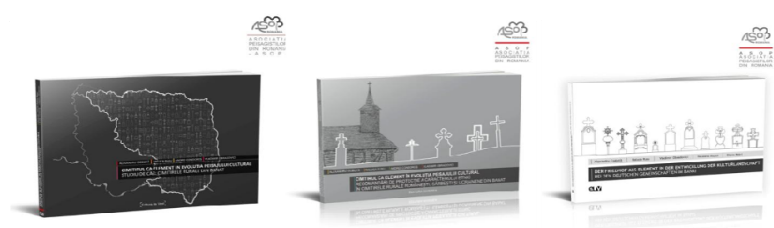

Fig. 1. The Romanian Landscape Architect's Association three year's study "The cemetery as an element in the evolution of the cultural landscape; case study: Banat Cemeteries" (original)

These studies were conducted in interdisciplinary teams of professionals in the fields of: history, anthropology, theology, architecture, urbanism and landscaping.

In 2013, within the framework of the research: "The cemetery as an element in the evolution of the cultural landscape; recommendations for the protection of the character in the Romanian, Serbian and Ukrainian rural cemeteries in Banat" the Făget Ethnographic territory was chosen as the study area [3].

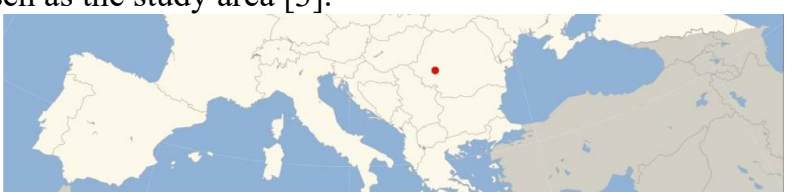

Fig. 2. Location of Crivina de Sus village (original)

This region of old Romanian communities, recorded since the Middle Ages, is a hilly area that has escaped the Habsburg colonization and partly the territorial systematization of the village tissue, according to the planned model applied to the rest of the Banat region. Within this area, the village of Crivina de Sus was chosen as a case study because of the rich cultural landscape it carries. Crivina de Sus is a typical valley village, still preserving architecture made entirely of wood also an old tradition of agricultural occupation and animal breeding, based on cultivated areas in the upper lends, outside the villages, where the summer shelters are built.
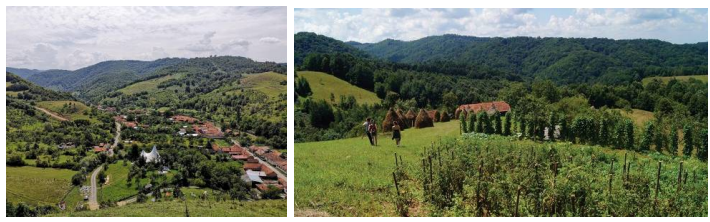

Fig. 3. Cultural landscape: village layout and vertical spatial relations / natural \& agricultural landscape (original)

The church of St. Parascheva, the oldest church still standing in the Banat area (1676) [4], its vertical placement on a hill related with the village in valley, the natural and the anthropic landscape, but also the local community with many difficulties and problems, determined us to choose this village as a case study.
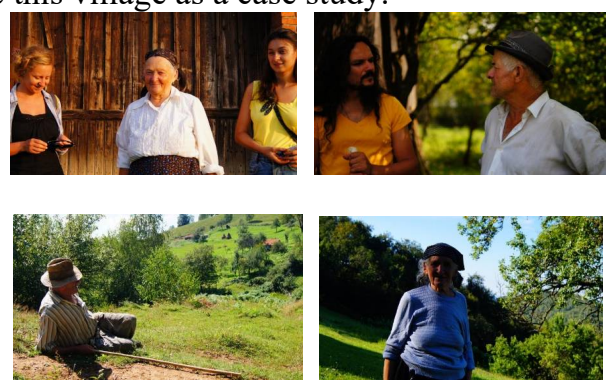

Fig. 4. Cultural landscape: the local community (original) 


\section{The interdisciplinary summer workshops}

\subsection{The fistre workshop (2013)}

This involved organizing a first interdisciplinary workshop in the summer of 2013 attended by specialists from various fields related to our research such as: anthropologists, theologists, artists, restorers, geographers, architects, urbanists, landscape architects and students from different fields such as: architecture, landscaping, restoration, theology and cultural studies. The workshop lasted two weeks, during which, each guest held a presentation of their research during the evenings, and during the day they held workshops on various topics such as landscape studies, urban studies, vernacular archaeological studies, social investigations and discussions with the local community, surveyes of the households and of the wooden church, study of the church's painted elements (the royal gates and the central crucifix), studies of the cemetery around the church and its monuments.
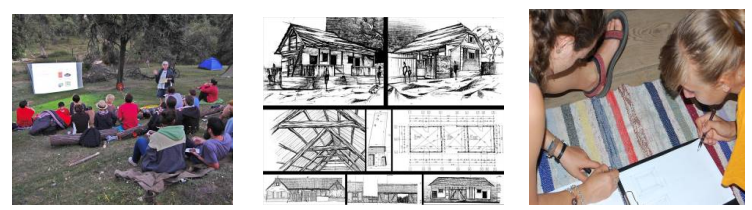

Fig. 5. Evening presentation / studies of traditional households / architectural measurements (original)

In addition to the studies, a number of reversible interventions in the landscape have been carried out: for ex. a local traditional entrance gate in the cemetery, instead of a inappropriate wire mesh, a wooden crucifix, that marks the path that goes up to the church and to the cemetery
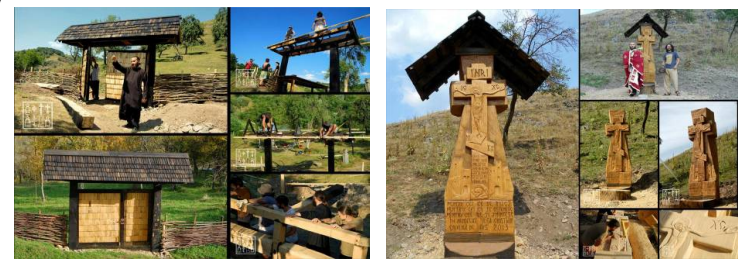

Fig. 6. Building a traditional aces gate in the cemetery / building a wooden crucifixe (original)

The whole research from 2013 and the studies at the Crivina de Sus workshop and their conclusions were published in the work "The cemetery as an element in the evolution of the cultural landscape; recommendations for the protection of the character in the Romanian, Serbian and Ukrainian rural cemeteries in Banat".[5]

From the interdisciplinary studies of the summer workshop in 2013, we gained understanding of many aspects of the cultural landscape of Crivina de Sus, and in the next year we decided to continue the summer school, because we considered that such an amount of studies and energy invested, would be a pity to be abandoned. The intention was to continue to get involved, to help solve some problems identified in the study. Priority became the wooden church, the monument being in a very poor state of conservation.

We can conclude that we have decided to continue the project, by understanding the potential of the entire cultural landscape: the local community, the productive and natural landscape, the built heritage: the settlement, the cemetery and the wooden monuments. The objectives throughout the future workshops were focused in this three directions: the man, the landscape, the built heritage and the relations between them. 


\subsection{The following workshops and activities (2014-2018)}

The summer 2014 workshop was organized in similar way as in 2013, with participant students from different fields, the majority being from architecture and invited specialists from different fields who held presentations and workshops during the two weeks of the camp. We continued the studies started the year before, and focused on the wooden church. The practical interventions continued, rebuilding some ancient funeral wooden crosses and columns of the cemetery being in a poor conservation status, and also we continued the traditional fence around the cemetery.
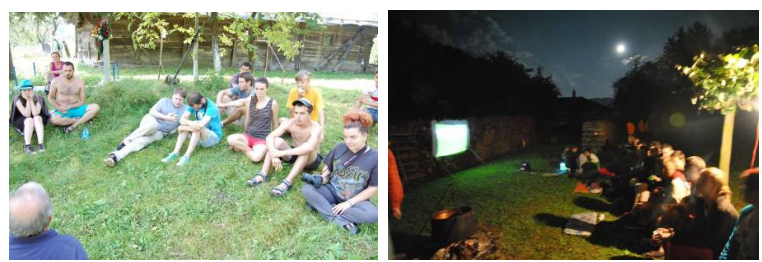

Fig. 7. Discussions between gusts and students / Evening presentation (original)

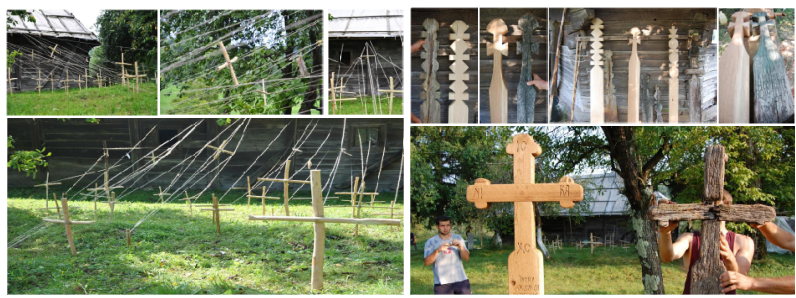

Fig. 8. Art instalation workshop/ The restoration of wooden monuments (original)

In the summer of 2015 a new workshop was built around the wooden church, where we began to survey in detail the wooden elements of the church. One of the aims of the workshop was to invent and prepare an analysis sheet for each element of the church.

The specialists from the fields related to our project were invited to the workshop, including the architect Alexandru Babos, specialized in studying the traditional wood heritage, especially the old wooden churches. He had a presentation on the topic: "The Reading and the Evaluation of the Wooden Monuments Churches in the Padureni Region".

At this workshop we also built the small access gate in the cemetery (on the southern side), also in a traditional technique of the big gate, built in the summer of 2013
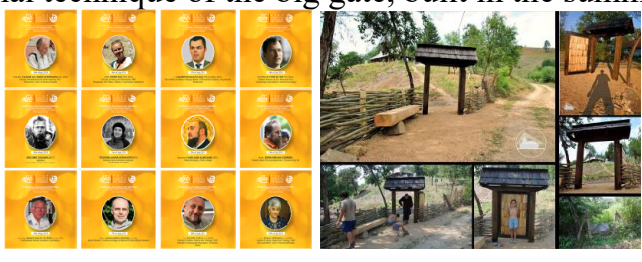

Fig. 9. Invited guests and specialists / Building the second gate for the cemetery (original)

In the winter of 2015 for three days (18-20 December 2015) a protection scaffold over the wooden church was buit in a inovative way.
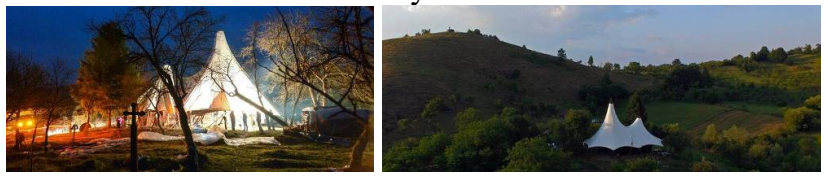

Fig. 10. Mounting of the scaffold / The scaffold today (original) 
In the spring of 2016, a workshop was held in which the known biologist Livia Bucsa and the dendrocronologist, Mr. Istvan Botar, were invited.
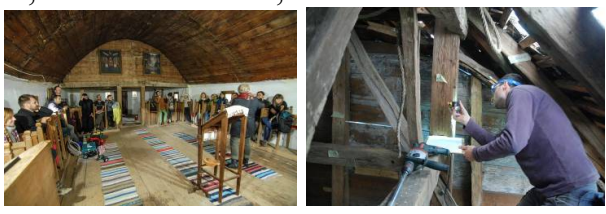

Fig. 11. Biological survey workshop / Dendrocronolical survey workshop (original)

Following the scaffolding and the removal of the old degraded shingle, at the summer workshop in 2016, we had access to the upper part, and we were able to record and draw up analytical charts for the elements in the upper part of the church.

Research on the cultural landscape continued, and studies were made on the productive land of how agriculture shaped the landscape. An understanding of how the nature was used as a resource, where the anthropic was in perfect balance with the natural, was pursued. Ways in which today this resource can be exploited for the sustainability of the community without losing its balance, were the questions to be responsed to.

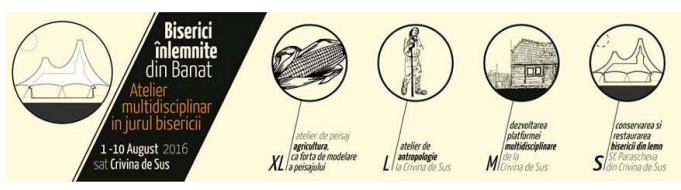

Fig. 12. 01-10 August 2016. workshops : productive landscape, anthropology, restoration (original)
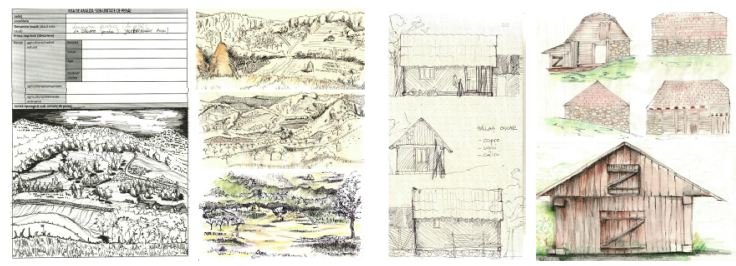

Fig. 13. Landscape studies workshops - productive landscape / summer shelters (original)

The summer camp was also attended by many specialists and men of culture, who held presentations on various themes, for ex. professor Prof. Constantin Jinga, dr. Adriana Babeţi, prof. Otilia Hedeşan, Assist. Raluca Boboc, Professor Daniel Vighi, Viorel Marineasa, Ovidiu Forai, Sociologist drd. Iosif Csatos-Dima, landscaper Nicolas Triboi, lecturer univ. dr. arch. Mihaela Hărmănescu, artist and scientist lect. univ. Dr. Gabriel Kelemen.

Next year (2017), steps were taken to prepare the restoration documentation to obtain the building permit. The summer restoration workshop of that year was used to bring together the entire design team and to have an interdisciplinary dialogue based on all the discoveries made in the earlier stages and to correlate and agree on the future interventions needed to restore the church. Together there were a few days of presentations of the conclusions of each discipline and discussions between disciplines and specialists, this discussions were attended by students, some of whom became part of the project (arch. Moldovan, arch. Sorin Silaghi, arch. Ariana Ţuţuianu.). The participating students, prepared 3D simulations of the stages through which our wooden church passed according to the historical study.

On Feb. 12, 2018, in the vegetative rest period and a decreasing moon, we cut traditional, manually, six oak trees needed to replace the rotten bottom beams of the church. 
The student workshop held in the summer of 2018 was less intense compared to previous years, exercises were held with the students participating in the understanding of the wooden church from several perspectives, the restoration project was presented and we visited craftsmen from the area who still work traditional crafts, such as smiths and carpenters. Also the studies on the landscape were carried out.
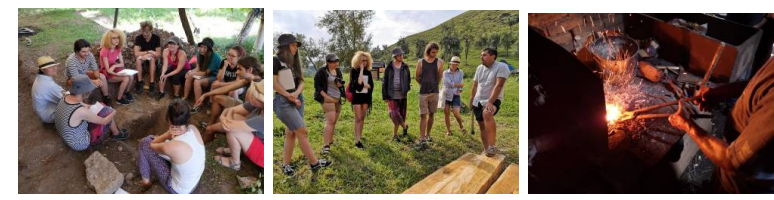

Fig. 14. Heritage related discussions / visiting traditional craftsmen (original)

In 15 'th of July 2019 another interdisciplinary workshop will be held where the entire design team will be invited to hold a discussion on what has been done until now, and together with the students and craftspeople we will prepare the interior earth plastering of the church, and the stone pavement around it.

\section{Concrete results and conclusions}

The workshops and events of all these years have given us a deep interdisciplinary understanding of the context, a process that we have tried to share through media channels and the internet. Also concrete actions have arisen:

After the first workshop in 2013, the research and findings were published in "The cemetery as an element in the evolution of the cultural landscape; for the protection of the character in the Romanian, Serbian and Ukrainian rural cemeteries in Banat. " [6]

In 2015, we were part of the PLAI Festival, with a pavilion speaking about the state of the wood heritage in Romania. [7]
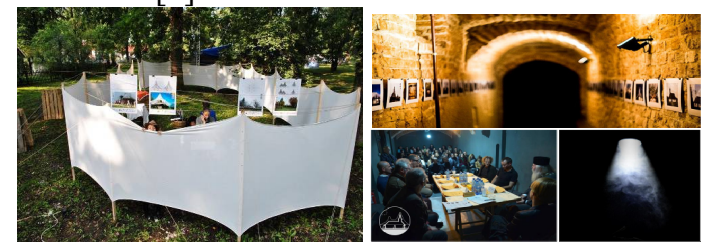

Fig. 15. Participation at PLAI to draw attention to the wood heritage and found raising / THE WOODEN MIRROR publicizing discussions about the situation of the wooden heritage (original)

In 2016 we organized the exhibition "Wooden Mirror" to draw attention of the poor state of the wooden heritage in our country.

In 2018 a presentation was presented to the pupils from the villages of Pietroasa on heritage issues.
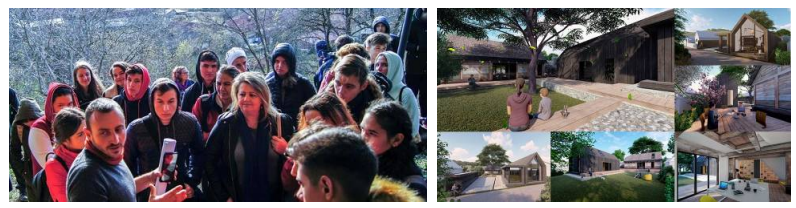

Fig. 16. Education in heritage for children / Ariana Tutuianu's diploma project for a research center for wooden heritage conservation in Crivina de Sus (original)

In 2018 the sudent Ariana Tutuianu, prepared here diploma at the Faculty of Architecture in Timisoara, having the theme "A Restoration Center for the wooden heritage". 
The minus of this project could be related to the little involvement of the local community in this process, having only a few beautiful moments when young people in the village came help us and attend the workshops. We would have enjoyed the learning process being reciprocal between us coming from outside and the local community, but this is a subject of another article.

\section{References}

1. https://www.afcn.ro

2. A. Ciobotă, R. Rusu, A. Condoroș, V. Obradovici, Cimitirul ca element în evoluția peisajului cultural; studiu de caz: Cimitirele rurale din Banat, Ed.Universității de Vest, Timişoara, (2012)

3. A. Ciobotă, R. Rusu, A. Condoroș, V. Obradovici, Cimitirul ca element în evoluția peisajului cultural; Recomandări de protecție a caracterului etnic în cimitirele rurale românești, sârbești și ucrainiene din Banat, Ed.Învierea, Timişoara, (2013)

4. https://ro.wikipedia.org/wiki/Biserica_de_lemn_din_Crivina_de_Sus

5. A. Ciobotă, R. Rusu, A. Condoroș, V. Obradovici, Cimitirul ca element în evoluția peisajului cultural; Recomandări de protecție a caracterului etnic în cimitirele rurale românești, sârbești și ucrainiene din Banat, Ed.Învierea, Timişoara, (2013)

6. ibidem

7. http://www.plai.ro/festival/en/plai-festival-2015/ 